\title{
港湾における長周期波対策の現状と課題 PRACTICAL COUNTERMEASURE TO LONG PERIOD WAVE IN HARBOR
}

\author{
平石哲也 1 平山克也 2 \\ Tetsuya HIRAISHI and Katsuya HIRAYAMA \\ 1 正会員 工博 港湾空港技術研究所海洋・水工部（テ239-0826 横須賀市長瀬3-1-1）
}

2正会員 工修 港湾空港技術研究所海洋・水工部（干239-0826 横須賀市長瀬3-1-1）

\begin{abstract}
Long period waves with period of 30 to 300 s causes the troubles in loading and un-loading of large cargo vessels and breaks of mooring ropes. Such damages are amplified by the resonance of mooring system composed of vessel and hawser to long period waves because the natural oscillation period of the system agrees with that of waves. The countermeasures represented by the extension of offshore breakwaters, improvement of mooring system and establishment to warning system have becn proposed to prevent the long periud wave turbulence.

In the paper, the practical countermeasures employing the extension of offshore breakwater and development of long period wave absorber are proposed. Numerical modeling is carried out to evaluate the effects of countermeasures to reduce long period wave heights in harbor. The simulated results demonstrate that offshore breakwaters extended appropriately may reduce the incident energy of long period waves and may increase the rate of effective handling days and that double slit caisson sea wall is applicable to reduce the energy of reflected long period waves.
\end{abstract}

Key Words : effective handling days, harbor tranquility, long period wave, numerical simulation

\section{1.はじめに}

周期数分の長周期波の侵入によって，水深が深い 岸壁に係留された大型貨物船やコンテナ船が大きな 水平運動を引き起こし, 荷役が中断されたり, 係留 ロープや防舷材が破損する事故が全国で生じている。 荷役の安全性を確保したり，港湾の荷役作業の定時 性を向上させ，経済的な運営を行うためには，この ような長周期波による荷役障害を軽減させる必要が ある。 また，最近は，できるだけ荷役時間を短縮さ せ，大型船の接岸時間を短くすることが，輸送コス トを低減させる効果があるために，船体の動摇を抑 えて荷役作業を迅速に行うことが必須となっている.

長周期波による荷役障害は，大型船と係船索から なる係留系の固有振動周期が 1 ～数分程度になり, 港湾に入る波の周期と一致して, 共振現象を生じる ことが，主な原因となっている"。したがって，こ の対策としては，まず係留索の材質や初期張力を変 更して，固有周期を変えて共振運動を抑止すること が考えられる. しかし, 固有周期を大きく変化させ るためには, 繊維やナイロン系の化学繊維で製作さ れている通常の係船索に変えてワイヤ一等の非常に 固いロープを使うことになり, 附帯設備の更新も必 要で, 能代港 ${ }^{2)}$ 以外では実用化されていない。
短期的な対策として注目されているのは，長周期 波の発生時刻を予測して, 船舶の寄港時刻や荷役時 刻を調整して障害が発生しないようにする，いわゆ る“長周期波警報システム”の構築である。港湾工 事における施工計画の作成のために各港毎に行われ ている風波の短期予報值から，経験式で港内長周期 波を予測する手法 ${ }^{11}$ は，苫小牧港ですでに運用され ており，鹿島港でも運用準備がされている。ただし， この手法は, 経験式の精度に問題を残しており，長 周期波高が設定した警戒值を超える時間を時刻は推 定できるものの，波高の最大值や変化の傾向を止確 に予測するためには，波向きに関する情報を考慮で きるように改善する必要がある.

もう…つの対策は，防波堤の延伸や波除堤の新設 によって侵入する長周期波のエネルギーを低減させ， 結果的に共振で生じる大型船の動摇振幅を抑制する ものである. 苫小牧港や能代港の沖防波堤の新設に よる長周期波の低下に関する数值計算 ${ }^{1)}$ によれば, 長周期波の伝播波向に対して直角に防波堤を延伸す ることで，港内における長周期波高を低減できるこ とを示し，港湾計画の策定に活用されている．この 対策は，通常の風波に対しても有効で，港内の静穏 海域を拡大させ水産養殖施設の設置場所を增やす効 果を有するので，全国の荷役障害が発生している港 
湾で検討されている，ただし，港湾施設を整備して 閉じられた水域を形成することは, 副振動を励起し て小型船の係留障害を及ぼす可能性があり, 配置計 画策定には詳細な検討が必要である.

また, 防波堤の延伸は, 現在の港几部より深い海 域での工事を必要とするので, 単位長さあたりに要 する工事費が增大する。したがって，侵入エネル ギーを低減させるだけでなく, 港内での反射を無く し，港内に入射した長周期波が港内で増幅されるこ とを抑止する手法も同時に推奨すべきである. 本調 查では, 港湾構造物による長周期波対策の事例とそ の効果を整理するとともに, 建設時の課題を示した. さらに, 港内の消波機能を高める手法を示した.

\section{2. 長周期波対策工の評価}

港湾は通常, 沖合に長大な防波堤を有し, 風波の 侵入を防ぎ，港内の静穏を保っている。ここでは最 も沖側に位置し, 港内静穏度の確保におもな役割を 果たす防波堤を “沖合防波堤”とよぶ。沖合防波堤 を延伸すると, 長周期波の抑止に効果があるだけで なく, 風波に対する静穏度を向上させ, 港湾の安全 性を高めることができる．沖合防波堤の延伸や屈曲 による長周期波の低隇効果を推定し, 同時に岸壁に 倸留された船体の動摇計算を時間領域で実施するに は, 港内の長周期波形を算出しておく必要がある.

計算には，長波の分散性と非線型性が考慮できる修 止ブシネスクモデルによる波浪変形計算法を活用す る手法が幅広く用いられている．本計算法のプログ ラム ${ }^{31}$ は，その任意反射境界部分を除いたものが港 湾空港技術研究所NOWT-PARI Ver. $4.6 \beta$ として港湾 設計者に配布されている.

図一 1 は，小名浜港を例として”NOWT-PARI”を用 いた計算結果の中で港内波高比の分布を示したもの である。入射波は，波向ESEで，有義波高 HI1/3が $0.2 \mathrm{~m}$, 有義波周期 $60 \mathrm{sec}$ の単一方向長周期波である. 計算格子は, 波長の $1 / 10$ 程度を必要とするため風波 成分の計算では $5 \mathrm{~m}$ 程度の詳細格子を必要とする.

ここでは, 長周期波成分のみを入射させたので格子 間隔は $50 \mathrm{~m}$ である。入射長周期波の波形は，標準又 ペクトルの近似形"ににおててネルギー密度 $m b=H 11 / 3^{2} / 16$ として算出した。 図一 2 に港口部 M, 港内のP 1 およびP 2 における計算波形を示す。港 内のバース P 1 では, 長周期波高は40\%に低減され ており，沖合防波堤の効果が現れている．さらに港 奥側のP 2 では波高は $80 \%$ 程度にしか低下していな い。これは，バース位置の水域において反射波によ る增幅が生じており，防波堤の軽減効果を打ち消す ような現象が生じているためである. また波形を外 力として係留船舶の動摇計算が可能になる.

長周期波の低減率を定量的に推定できる計算法は 確立されたものの，どこまで防波堤を延伸すれば所 定の目的を果たせるかどうかについては別途の指標 が必要である. 現在, 指標として幅広く使われてい

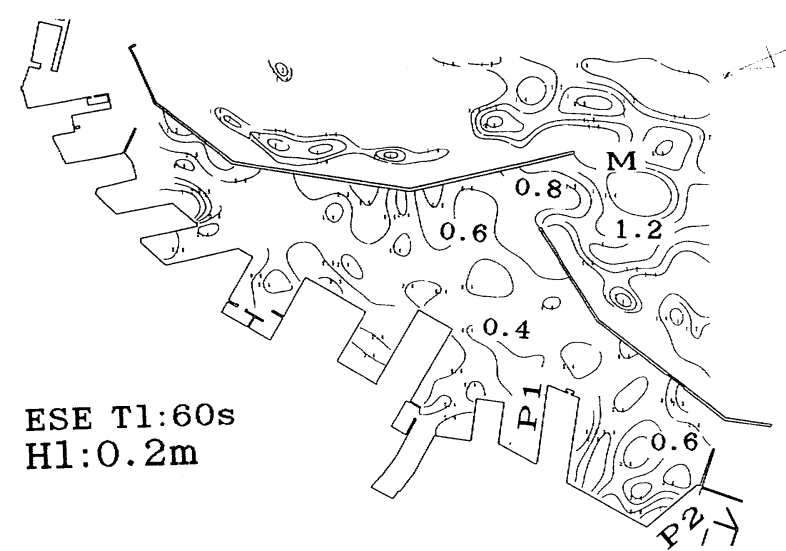

図一 1 小名浜港における港内長周期波高比

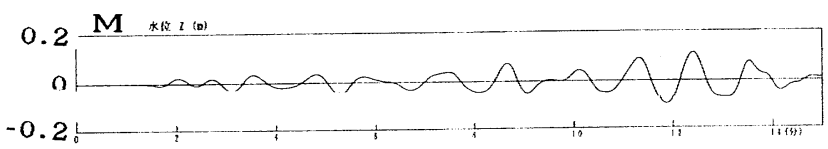

P 1

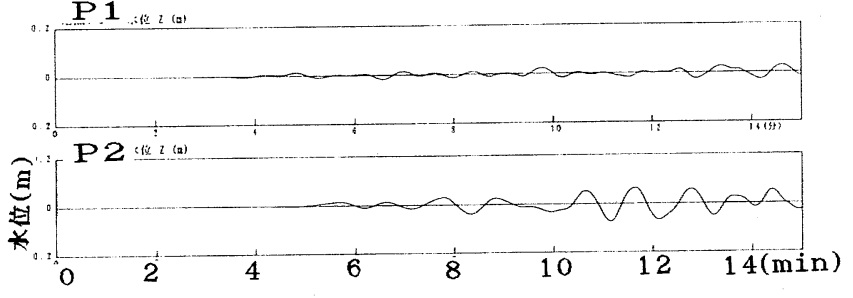

図一2 港内の計算長周期波形

るものは荷役稼働率である. 荷役稼働率は, 対象岸 壁前面の長周期波高が荷役限界波高以下のなる日数 の年間出現率で, 風波成分に対する目標率 $97.5 \%$ が 長周期波に対しても目標值となる。荷役限界波高は, 苫小牧港の船体動摇観测から標準値として有義値で $10 \mathrm{~cm}$ が提案されている"が, 港湾の荷役施設の機械 化が進むと, 荷役効率を上げるためより小さい值が 必要とされると思わ机る. また, 荷役に従事する労 働者の高齢化も考慮して, 各港毎のヒアリング調査 に基づいた設定が重要である. 宮城県石巻港引等で は, 船体運動と港内波高の同時観測を実施して, サージング運動の応答関数を求め, 提案されている ${ }^{6)}$ サージング両振幅の許容值 $2.0 \mathrm{~m}$ を満足する荷役限 界波高として有義波高 $8.0 \mathrm{~cm}$ を提案している. 港外 の長周期波の頻度分布は, 風波の頻度分布から長周 期波標準スペクトル形で計算した ${ }^{4)}$ 。

図一 3 は, 荷役稼働率の計算例として第 2 期の拡 張計画が検討されている茨城県常陸那坷港における 計算例を示したものである. 図中の岸壁P 2，G 1 ， G 2 では, 長周期波に対する荷役障害の発生が懸念 されているため図に示す波除堤案が提案されている. また, 将来の完成港形における荷役稼働率の算出が 必要とされている. 図一 4 に, 現在, 波除堤案 1 の 場合, 波除堤案 2 の場合および将来港形の場合にお ける対象岸壁の荷役稼働率を示す. 防波堤の屈曲に 相当する波除堤案 1 の場合は, 現状の稼働率を向上 させることが可能で対策工として有効である. 将来 港形の場合には, 現状の港形では開放されている図 
- 3 の左側海域からの入射エネルギーが抑止される ので，荷役稼㗢率を100\%まで上昇させることができ， 安全な港湾を形成できる. 複数基を有する波除堤案 2 の場合には, 単基波除堤の案 1 より荷役稼働率が 低下する。これは，波除堤間で反射波が発生し，港 内の合成波高を上昇させたためで，対策工の配置案 検討には反射波による增幅も考慮する必要がある.

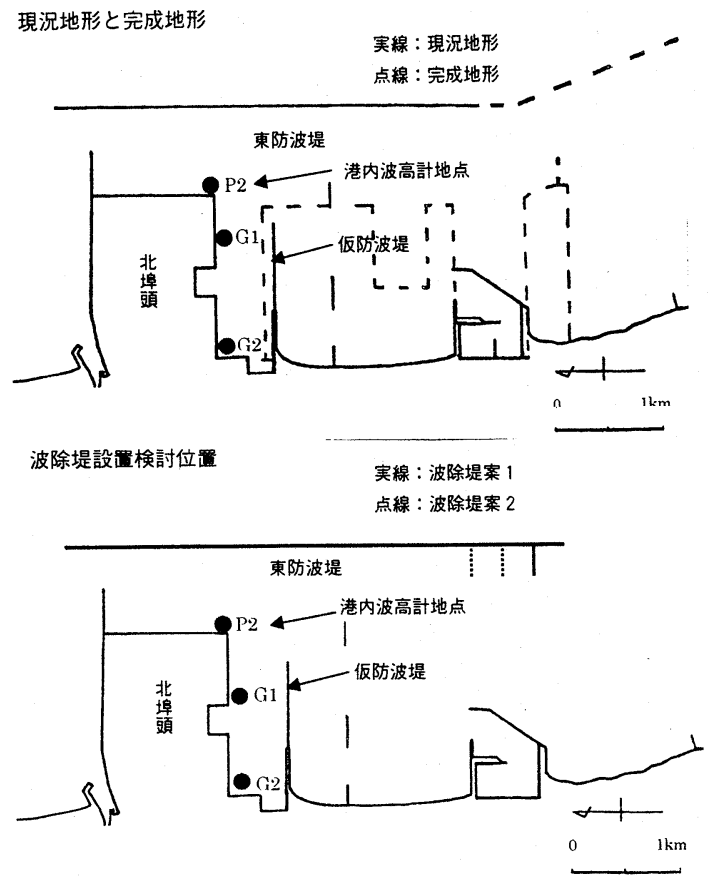

図一 3 茨城県常陸那坷港の対策工の配置案

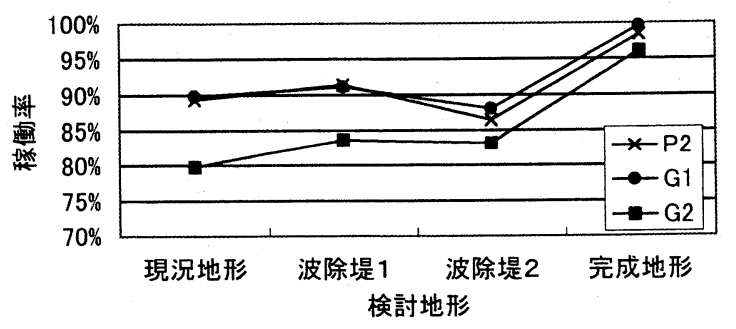

図一４対策工による荷役稼働率の変化

\section{3. 長周期波対策工の事例と課題}

\section{（1）宮城県石巻港の場合}

ここでは，長周期波対策用の防波堤が計画され， 配置案と施工性が議論されている宮崎県石巻港と宮 崎県細島港を例にして, 対策工の効果の算定例と建 設にあたっての課題を示す。

図一 5 は，石巻港における防波堤延長計画の一例 である．港内の大水深バース Bの整備にあたっては， 現在の暫定供用中でも係船索の切断が報告されてお り, 将来, 入港船舶数が増加すれば事故例も増える 危険性がある，そこで，風波に対する静穏度も向上 させる目的で図中の沖合防波堤0Bを東側および西側 へ延伸する計画である. 同時に延伸することはでき ないので, 効率の良い施工手順と将来の必要延伸長 を算定するために長周期波に対する稼働率計算を

行った。なお, 防波堤の延伸形状は, 航路の運航性 等にも配慮して決定されるので, ここに示した配置 案は計算のための例題で, 現地の計画部局で実際に 議論されている将来港形とは異なる。

r-21: $958 m$
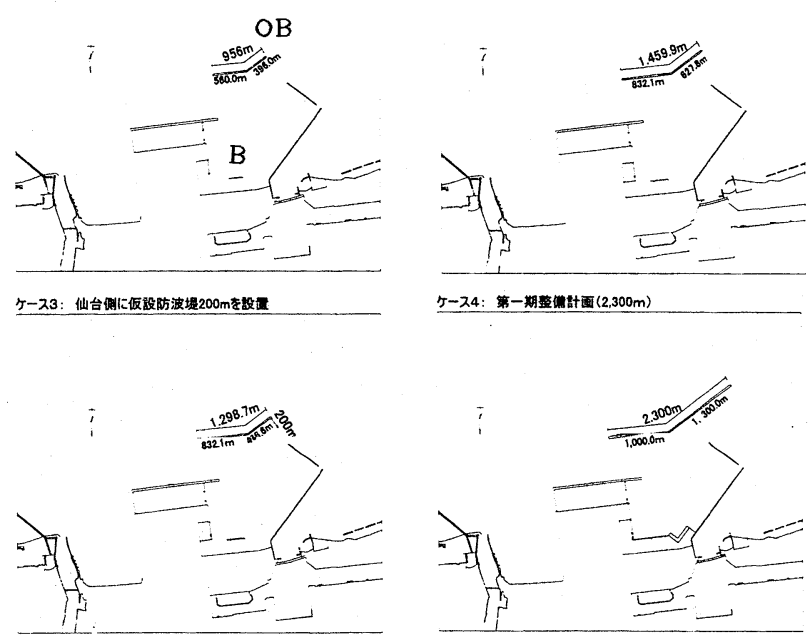

図一 5 石巻港における防波堤延伸計画の例

図のケース 1 は, 現況で, 防波堤延長は $956 \mathrm{~m}$ であ る. ケース 2 では, 風波の最頻出現波向SEに対する ために, 東側へ約 $300 \mathrm{~m}$, 西側へ約 $200 \mathrm{~m}$ 延伸されてい る. ケース 3 は, 長周期波の最頻出現波向Sに配慮 するとともに，完成までの暫定港形として，将来沖 側へ設置するケーソンを港部に仮置きして波除堤 に利用したもので，西側港口部の南に200mの波除堤 が設置されている.ケース 4 は，波除堤を取り外し， 沖合防波堤を延伸したケースで, 現状よちも東およ

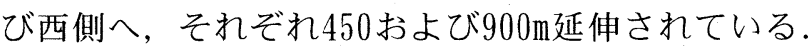

図一 4 で示した常陸那珂港の例では, 長周期波の 波向は，風波の波向と同一と仮定されている．沖側 から入射する長周期波のエネルギーの大部分は自由 進行長波として伝播すると考えると, 洋上の低気圧 によって生成される長周期波の伝播方向は, 比較的 陸岸に近いところで発生する風波成分の波向とは 致しない可能性が高い。そこで，石巻港では， 2000 年の代表期間に現地観測を行って, 長周期波の波高 および波向の頻度を求めている。観测点は水深 $25 \mathrm{~m}$ の地点で, 超音波式波高計および水平 2 成分電磁流 速計を設置し，長周期波の波向は，2 成分流速の平 均流向として定義した ${ }^{5)}$.

図一6に観測結果から得られた風波および長周期 波の波向出現頻度を示す。風波の最頻出現波向はSE およびSSEで，SからEまでほぼ均一に波向が現れて いる. 長周期波の最頻出現波向はSで，Sが卓越した 出現率を示している。したがって，風波と同一の波 向として長周期波を入力すると, 最頻出現波向を考 慮しない場合があり, 現状と異なる結果を出力して しまう危険性がある。図の波向頻度分布は 1 年間の 観測結果から導かれており代表値として採用するた 
めには観測期間が不足している. 今後は, 長周期波 の観測例を增やして波向に関する情報をより多く蓄 積していく必要がある。 また，長周期波は風波より も多方向性が強い場合があり门，入射波として多方 向不規則波を設定する必要が生じている.

表一 1 は，石巻港のモデル港形に対する長周期波 荷役稼働率の計算結果である。荷役限界波高は $8 \mathrm{~cm}$ とした．現況では，稼働率が $66 \%$ で低いが，防波堤 を延伸することで，稼働率を上昇させ $80 \%$ 以上にす ることができる。 ケース 3 の仮設堤による稼働率は, 完成形とほぼ同じで, 短期間で稼働率を向上させる 手段之して，似設堤の活用が有効になる場合がある.

なお，エネルギーレベルから長周期波高を表す場 合には, 周波数スペクトルの長周期波成分の 0 次 モ一メントから, $H 11 / 3=4(m)^{0.5}$ で算出されるが, 船 体動摇などで使う波形からゼロアップクロス法で定 義される有義波高とは相違する。図一7は，2000年 の観测波形から，スペクトル0次モーメントとして 算出された波高を横軸に，ゼロアップクロス法で算 出された波高を縦軸に示したものである。ゼロアッ プクロス法で求めた波高は，スペクトルによって計 算した波高の0.9倍程度になり, 算出法の違いによ る波高統計量が相違することに注意する必要もある.
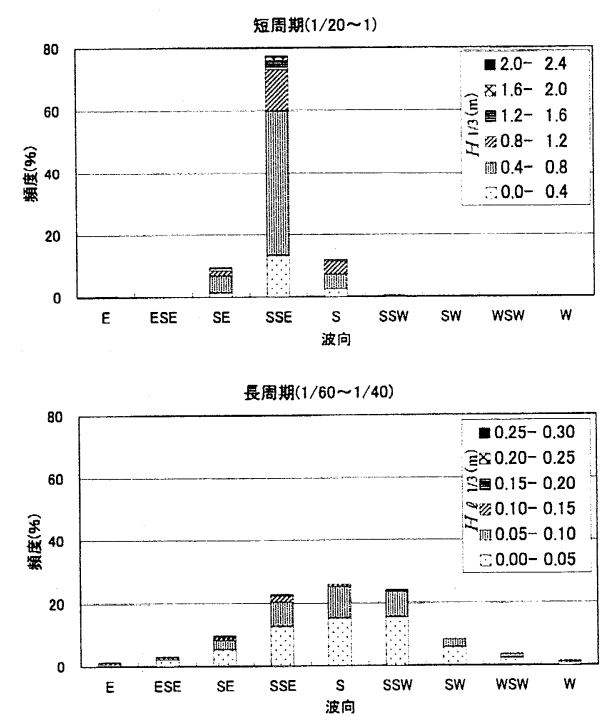

図一6 石巻港における波向出現頻度

表一 1 長周期波対策工による荷役稼働率の変化

\begin{tabular}{|l|l|c|}
\hline 港 形 & 防波堤延長 & 港内平均荷役稼働率 \\
\hline 現 状 & $956 \mathrm{~m}$ & $66 \%$ \\
\hline 東西延長 & $1459 \mathrm{~m}$ & $80 \%$ \\
\hline 西側改良 & $1299 \mathrm{~m}+$ 波除堤 & $80.9 \%$ \\
\hline 完成港形 & $2300 \mathrm{~m}$ & $81.6 \%$ \\
\hline
\end{tabular}

\section{（2）宮崎県細島港の場合}

宮崎県細島港は, 商業港および工業港地区を有し, 国際貿易港としても発展しているが, 以前から長周 期波による荷役障害が報告されており, 現地観測に

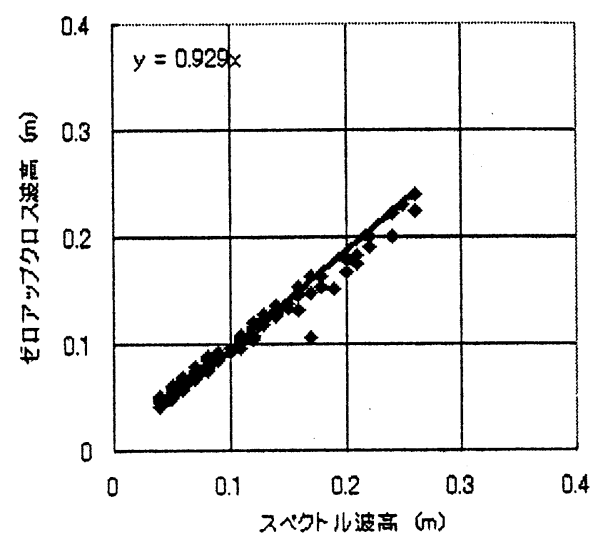

図一7 ゼロアップクロス法とスペクトル形から 算出された有義波高の比較

おいても沖合での長周期波の発生頻度が高い港湾の 一つになっている. 現在, 港口部に沖合防波堤を設 置して港内の長周期波を低減させる計画が進んでい る. 図一 8 に細島港の長周期波対策防波堤の位置を 示す. 防波堤は北堤および南堤からなり，それぞれ 総延長が750および600mである. 長周期波対策の沖 合防波堤は, 設置場所の水深が大きいことと, 設計 波高が高いことから大規模なマウンドとケーソンを 必要とし, 建設費が膨大になる。細島港では, 建設 コストの軽減を図るため, 防波堤の - 部を沖合の浅 瀬上に建設し, ケーソン堤体下部のマウンドの捨て 石量を縮減する施工案が採用された。また, 海中の 浅瀬を利用することで, 防波堤マウンドからの長周 期波エネルギーの浸透を防いでいる.

一方, 海中に位置する浅瀬は屈折によって波の工 ネルギーを集中させる効果を有しており, 多方向波 を作用させたときの波高增大が模型実験でも明らか になっている ${ }^{81}$. 浅瀬上に防波堤の堤頭部が位置す る場合には，增大した波高と波の回折効果により， 消波を目的とした被覆ブロックの安定性が水深の深 い堤幹部より著しく低下する。 そこで, 断面実験で の安定性評価をもとに設定した被覆ブロックが堤頭 部でどのような挙動をするかを, 多方向不規則波造 波水槽で調べた。 図一 9 は, 堤幹部において被害率 $3 \%$, 堤頭部において被害率5\%を満足するように重量 を定めたブロックの配置案である. 堤幹部では50ト

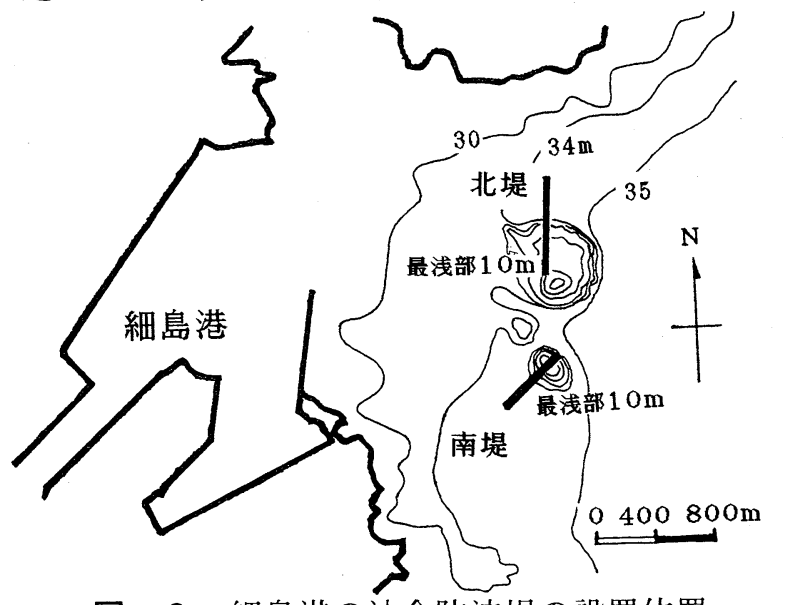

図-8 細島港の沖合防波堤の設置位置 


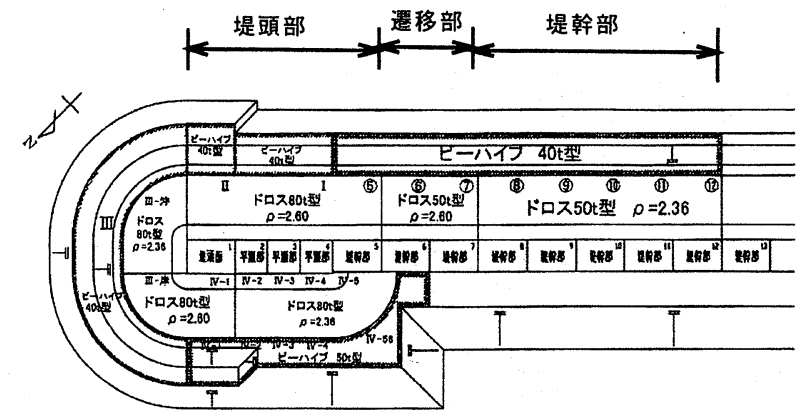

図ー9 模型実験によって設定した堤頭部の被覆 ブロックの配置

ン型ドロスの消波ブロックで安定性を得られるが, 堤頭部や堤頭函の裏側においては, 屈折による波の 集中と背後への回折波の影響が大きく, ブロックの 重量を大きくしないと安定しない. 図に示すように, ブロックは, $60 \%$ 程度重量を增した 80 トン型のドロ スを採用し, 被害率が局所的に高くなるケーソン角 部においては高比重のブロックを使用している。こ のように, 長周期波対策として沖合の大水深海域へ 防波堤を延伸する場合には, 海底地形の条件によっ ては, 従来の断面実験結果から得られる消波ブロッ クよりも，60\%以上重量を增加させたものを被覆層 として使用しなければならず，多方向不規則波中で の被覆ブロックの安定性の検討が課題として現れる.

\section{4. 港内における長周期波の消波}

周期 30 s以上の長周期波を港内の岸壁やスリット ケーソンや異形ブロックからなる消波護岸で吸収す ることは困難である。 そのため, 港奥では長周期波 が反射のために波高增大を引き起こし, 沖合防波堤 のために入射エネルギ一を減少させても，港内では 長周期波高が減少しないことが生じる. 逆に, 多重 反射系の構成により, 岸壁の整備が進むと港奥の波 高が增大するという逆説的な結果を生む要因となる。

長周期波の反射特性については, 波崎海岸での解 析例" があり, 砂浜海岸では反射率が 0.7 以下になる ことが示されている. そこで, 港内でも自然や人工 の砂浜や干潟が存在しておれば，港奥での多重反射 が防止できると考えられる. 港内の自然海浜の残存 率と長周期波の波高分布の定量的な関係は調査例が 無いので, 明確な推定はできないが，全国的にも， 整備が進んでおらず自然の砂浜や干潟が港内で多く 残っている港湾では, 近傍の港湾で長周期波の荷役 障害が報告されていても, 対象港湾での被害例は無 く, 静穏な水域が確保されているようである。この ような港湾の例として, 沖縄県那覇港, 宮崎県宮崎 港, 新潟県新潟東港があげられる。

船舶が大型化して大水深岸壁が必要になると港内 の航路掘削が実施されるので, 現在, 長周期波が問 題となっているような産業重点港において岸壁の近
傍に砂浜や人工干潟を建設することは難しい。そこ で, 消波護岸として幅広く使われているスリットケ 一ソン護岸を改良して，長周期波に対しても消波性 を有する護岸形状を提案した.

港湾で多用されているスリットケーソンタイプの 直立消波岸壁では遊水部の奥行きが数 $\mathrm{m}$ 程度であり, 周期数秒の風波しか消波できない。ここでは陸側に もスリットを有する両面スリットタイプのケーソン を活用し, 裏込め材に大型の雑石層を採用して, ケーソン背後にも幅の広い消波層を設けた消波護岸 を示す．護岸の裹込め材が雑石であり，荷役物揚場 として使用するためには, 上面の舗装手法などに課 題は残るが，スリット間隔を最小雑石径より小さく しておけば，吸い出し等の被害は生じない。図一10 に対象とした両面スリットケーソンのイメージを示 す. 図におけるケーソンの設置水深は $10 \mathrm{~m}$ で，ス リットの開口率は $50 \%$ とし，遊水部の幅は $10 \mathrm{~m}$ とし た. スリット開口部の高さは水面上 $1.0 \mathrm{~m}$ で，ケー ソン背後の消波層の幅は $40 \mathrm{~m}$ とした。図には, 従来 から港湾で多く用いられている片面にのみスリット 孔を有するスリットケーソン護岸も同・スケールで 示した。従来のものを, 片面スリットケーソンと呼 ぶ. 両面スリットケーソンの裹込め雑石としては粒 径 $20 \mathrm{~cm}$ の固形粒子を想定した.

片面および両面スリットケーソン護岸における長 周期波の反射特性を推定するために，3 次元の水粒 子の運動を流体直接解析法を用いて解析し, 入射波 形と反射波形を比較することを試みた。両面スリッ トケーソン壁に対してスリット有する多孔体からな る透水層として解析を行った。流体直接解析法 (MARS (Multi Art Resolve Solver) 法) は,これまで 栈橋の揚庄力の解析や遡上津波力の推定に応用した モデル ${ }^{10)}$ を用い, 図に示した長さ $1200 \mathrm{~m}$ の数值波動 水路を幅 $1.0 \mathrm{~m}$ の 3 次元格子で表した. 図の奥行き 方向の領域幅はスリットの形状が再現できるように $20 \mathrm{~m}$ とした。計算では，周期 30〜 60s で波高 $1.0 \mathrm{~m}$ の長周期波を， 2 波だけ入射境界から造波し，代表 点での波形を解析することによって反射率を求めた.

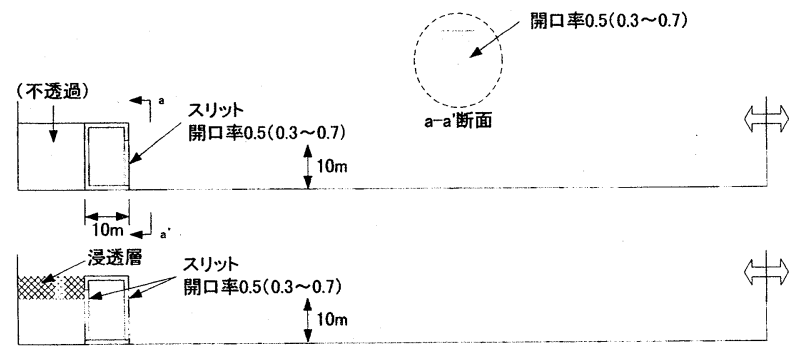

$$
\Leftrightarrow \text { 入射境界 }
$$

波浪条件 $\mathrm{H}=1.0 \mathrm{~m} \quad \mathrm{~T}=30 \mathrm{~s}, 60 \mathrm{~s}$

図ー10 計算で用いた片面および両面スリットケ ーソン護岸のイメージ 


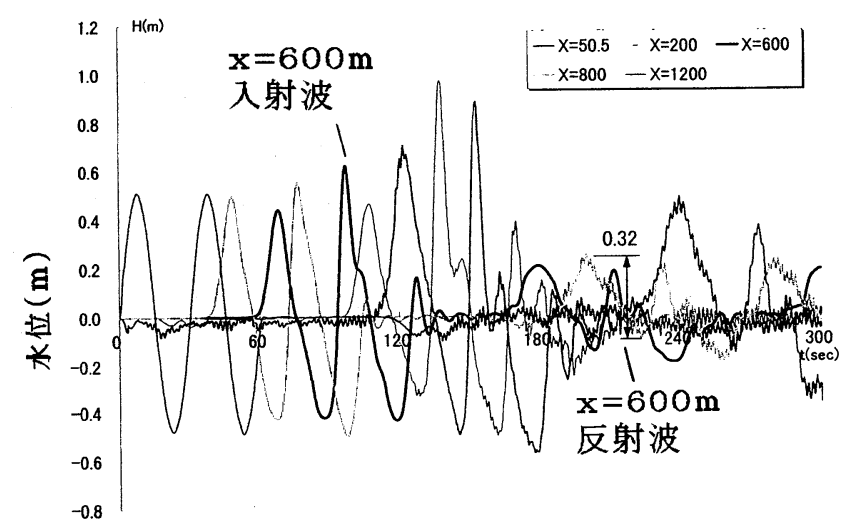

図－11 両面スリットケーソン護岸前面の波形

消波層内の庄力損失は粒径、空隙率、流体密度を考 慮して評価した。計算では透過層以外のすべての構 造物は不透過体としている.

図-11 は, 長周期波対応消波護岸前面の代表測 点における観测波形を示し, 位置 $\mathrm{x}$ は消波層背面か ら沖方向への距離を表す. $\mathrm{x}=600 \sim 800 \mathrm{~m}$ の長周期波 対策岸壁前面の测点では, 2 波の入射波が観測され た後に, 反射波が観測されている.片面スリットケ ーソン護岸では, 周期 $30 \mathrm{~s}$ で波高 $1.0 \mathrm{~m}$ の規則長周 期波の反射波高は，入射波と同様に約 $1.0 \mathrm{~m}$ となり， スリット内での消波は見られなかったが, 両面ス リットケーソン護岸の場合には, 図に示すように 反射波高は $0.32 \mathrm{~m}$ になる. したがって, 提案した消 波岸壁は周期 $30 \mathrm{~s}$ の長周期波に対して 0.3 程度の低 い反射率を確保でき, 港内における反射波吸収岸壁 として活用することが可能である.

最後に, モデル港の将来拡張案を対象に, 両面又 リットケーソン護岸や人工海浜を港奥に建設した場 合の港内長周期波宂の変化を調べた. 図ー12 は, 港内の壁面 B を直市壁とした場合と反射波吸収岸壁 と等価な人工海浜にした場合の長周期波成分の波高 分布を NOWT-PARI Ver. $4.6 \beta$ に任意反射境界を付加 したモデル ぼ求めた例で, 人工海浜にはスポン ジ層を配置し, 吸収係数を調整して所定の反射率が 得られるようにしている. 図に示すように, 港奥の 岸壁前面だけでなく, 港内の広い範囲にわたって波 高比は変化しており, 港奥部分を消波タイプとする ことによって, 港内の長周期波高をより小さくでき ることがわかる.

\section{5.あとがき}

本報告では，港湾の長周期波対策としては，沖合防 波堤の延伸や波除堤の新設で港湾に入射する長周期 波エネルギーを抑止する手法の効果を定量的に示す

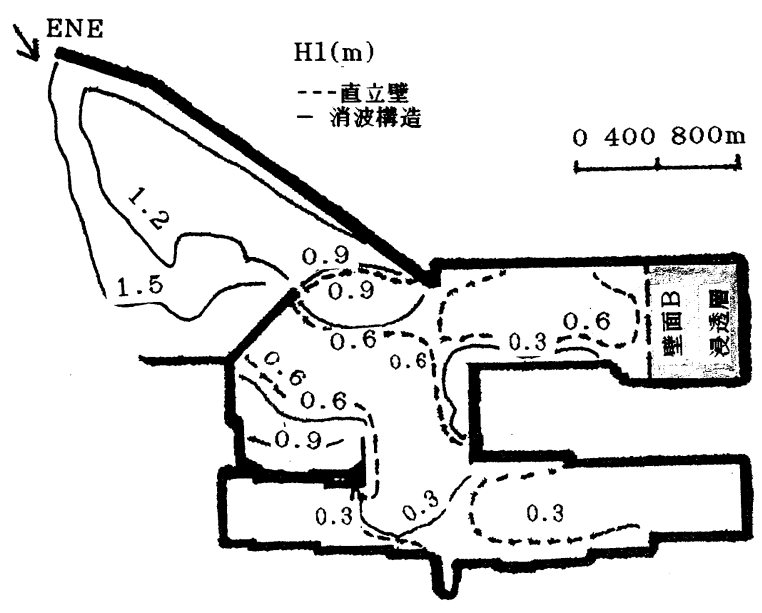

図ー12 消波岸壁を有する港湾の長周期波高分布

とともに，港内に長期波吸収岸壁を効果的に設置し て，反射波による長周期波の增大を防ぐことが重要 であることを示した。なお，本調査報告で用いた図 面および数值は，実際の現場設計に用いられている ものではなく，限定された観测データからの試計算 であることに留意されたい。

\section{参考文献}

1) 平石哲也 他6名：長周期波による港湾施設の被害特性 とその対策丁法に関する調査，港湾技研資料，No. 873 , 39p, 1997.

2) 白石悟 他3名:倸留システムに着目した長周期波に刘す る船舶の動摇抑制対策, 海丁.論文集, Vol.42, pp.941-945, 1995.

3）平山克也：ブシネスクモデルにおける透水層内の波浪 減衰を考慮した任意反射境界処理法の開発, 海岸丁. 学 論文集, Vol.48, pp.26-30, 2001.

4) 平石哲也：長周期波のエネルギーレベルとそれによる 荷役稼働率の推定, 港湾技研資料, N No. 934, 17p, 1999.

5) 平石哲也 他7名:発生頻度を考慮した長周期波対策丁法 の選定法, 海下.論文集, Vol.48, pp.1356-1360, 2001a.

6) Ueda S. and S. Shiraishi : The allowable ship motions for cargo handling at wharves, Report of Port and Harbour Res. Inst., Vol.27, No.4, pp.3-61, 1988

7) 阿部光信 他 2 名：現地観測データに基づく長周期波の 方向関数特性之静榣度解析への適用, 海丁.論文集, Vol.48, pp.266-270, 2001.

8) Vincent, C. L. and M. J. Briggs : Refraction-diffraction of irregular waves over a mound, ASCE, J. Waterways, Coastal and Ocean Eng., Vol.1 15, No.2, pp.269-284, 1989,

9) 岡安章夫 他 2 名: 厒波带内辰周期波の現地観测之数值計 算, 海丁.論文集, Vol.45, pp.286-290, 1998.

10)平石哲也 他 2 名: 南太平洋地域における植林による津波 刘策法の適用性,海工論文集,Vol.48, pp.1411-1415, 2001b. 